\title{
When products fail
}

Biotechnology companies have several options when it comes to alleviating the "sting" of failing to get a lead product to market, says Max Herrmann.

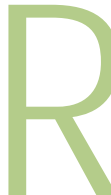

egardless of the turmoil currently being experienced by high-technology and biotechnology shares on stock markets around the world, the most significant risk to any individual biotechnology company remains the failure of a lead product in clinical development.

This was highlighted in December 2000 when news emerged that an advisory panel to the U S Food and Drug Administration declined to approve M axim Pharmaceuticals' (San Diego, CA) lead compound $M$ axamine for the treatment of patients with advanced metastatic melanoma and liver metas-

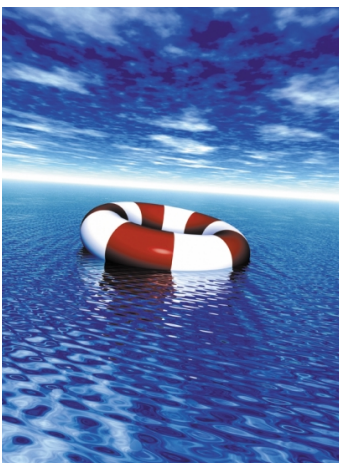
tases, questioning the drug's effectiveness; M axim's shares plummeted $44 \%$ in one day. M any other biotechnology companies with product failures have suffered a similar devastating loss of investor confidence.

Many companies have been criticized for their overdependence on one key product. However, unfortunately, this is rarely intentional. The high attrition rates seen in both drug discovery and clinical development mean that even initially broad-based businesses find themselves reliant on one successful development candidate.

Furthermore, with only around $10 \%$ of drugs that enter human clinical trials ever reaching the market, the list is growing of companies in the sorry position of having to deal with product failure.

H owever, companies that have suffered product failures have several options. These include renaming the company, closing it down, merging, changing the management, or refocusing drug discovery efforts. The strategy adopted depends on

Max Herrmann is vice president and pharmaceutical analyst at IN G Barings, London, UK (Max.Herrmann@ING-Barings.com). the company's cash position, the financial community's regard for its management, and the company's remaining development opportunities.

\section{A.K.A.}

Changing the name of the company is probably the most commonly used rescuestrategy, and its obvious purpose is to distance the renamed company from its past experiences. In the United Kingdom, for example, Cortecs (Cambridge, UK) changed its name to Provalis in November 1999 after its oral calcitonin drug, Macritonin, was not approved for the treatment of osteoporosis. Peptide Therapeutics changed its nameto Acambis (Cambridge, UK) after its lead allergy peptide vaccine failed in clinical development and the group shifted its focus from peptide-based drugs to vaccinedevelopment.

In the United States, Magainin

Pharmaceuticals (Philadelphia, PA) changed its name to Genaera in M arch 2001 after repeated development setbacks of M againin-based drugs.

\section{Disposing assets}

Disposal of what remains of a company's assets, and returning them to shareholders, is often the only strategy left open to biotechnology companies that are frequently short of financial resources.

Scotia Holdings (Stirling), one of the UK's early biotechnology stars, saw its share price collapse after theFDA failed to approve its photodynamic cancer therapy Foscan in October 2000. Foscan's rejection by European regulators in January 2001 proved to bethe final nail in Scotia's coffin, forcing the company into administration (Nat. Biotechnol. 19, 191, 2001). Although the company could have refocused its business on other drugs in its pipeline, a rescue fund-raising was futile: a $£ 50$ million convertible bond meant that any equity raised would have gone to the bondholders, not the shareholders.

Perhaps one of the highest profile drug failures in biotechnology's short history was that of Synergen's sepsis drug Antril, an interleukin-1 receptor antagonist. D espite a cash pile of $\$ 111$ million, Synergen agreed to a proposed acquisition by Amgen for $\$ 251$ million in December 1994. Synergen had decided 
that its future, and that of its employees, was best served as part of a larger group. Indeed, although the company is no more, this strategy has been successful and its drug pipeline lives on: The FDA is currently reviewing Kineret, a drug based on Antril, for the treatment of rheumatoid arthritis. If sales of Kineret achieve analyst expectations of $\$ 500$ million a year, Amgen's investment will have paid off handsomely.

\section{Musical chairs}

Failure of key products can also prompt investors to demand management changes. The recent high-profile failure of British Biotech's (Oxford, UK) anticancer drug $M$ arimastat, a matrix metalloproteinase inhibitor, is a good example.

Following press and investor accusations that the prospects for $M$ arimastat had been misrepresented, the company's shareholders decided that management needed to be changed. The company was well funded, having raised $f 143$ million in a follow-on offering in July 1996. However, several rounds of redundancies were required to

preserve the cash. Since then, $M$ arimastat has failed to show benefit in a broad clinical program.

\section{Perseverance pays}

Even the most successful biotechnology companies have suffered major product failures during their history. But some have

\section{Perhaps the best strategy of all is to reduce the potential impact a product failure could have in the first place.}

managed to cope by targeting the drug at another indication.

For instance, Celltech (Slough, UK) developed an antibody CDP571 to treat septic shock - a well-known graveyard for drug devel opment- and had licensed it to Bayer. When Bayer dropped development of the drug in M ay 1997, Celltech's shares fell $46 \%$ in one day. However, Celltech has since developed CDP571 for the treatment of Crohn's disease and could launch the drug next year. enthusiasm to raise funds for merger and acquisition activity and in-licensing, and to explore new product opportunities to diversify risk away from its lead product. The key objective is to broaden a company's pipeline without burdening the business with unacceptably high costs of clinical development.

Unfortunately, there will always be disappointments in drug development, and biotechnology companies and their investors need to be prepared for a bumpy ride. 